\title{
FAKTOR RISIKO OBESITAS SENTRAL PADA ORANG DEWASA DI DKI JAKARTA: Analisis Lanjut Data RISKESDAS 2007
}

\author{
Elya Sugianti'; Hardinsyah ${ }^{2}$ dan Nurfi Afriansyah ${ }^{3}$ \\ ${ }^{1}$ Alumnus Departemen Gizi Masyarakat, Fakultas Ekologi Manusia, IPB \\ ${ }^{2}$ Dekan Fakultas Ekologi Manusia IPB \\ ${ }^{3}$ Peneliti pada Pusat Penelitian dan Pengembangan Gizi dan Makanan Departemen Kesehatan RI
}

ABSTRACT

\section{RISK FACTORS OF CENTRAL OBESITY AMONG ADULTS IN DKI JAKARTA}

Obesity is now considered as a major public health problem, afflicting both developed and developing countries including Indonesia. Recently, central obesity, measured by waist circumference, draw a greater attention than overall obesity, measured by body mass index, since more risks have been proved to be associated with central obesity. The objective of the study is to analyzed risk factors associated with central obesity in DKI Jakarta. The study used secondary data of Basic Health Research (RISKESDAS) conducted in 2007 in DKI Jakarta. A Total of 11805 men and women age 15 year old or above excluding pregnant women were used for the analyses. Logistic regression analyses were used to measure the association between central obesity and existing variables in the data on the characteristic of subject. The result showed that significant risk factors associated with central obesity are age 35 year, sex (women), marital status (married), education (high school), occupation (entrepreneur/ tradesman/ services/ housewife), per capita income (quintile-5), fatty foods and mental disorders. Among those risk factors, sex (women) is the most determinant risk factor.

Keywords: central obesity, risk factors, Basic Health Research (RISKESDAS)

\section{PENDAHULUAN}

ewasa ini obesitas telah menjadi masalah kesehatan dan gizi masyarakat dunia, baik di negara maju maupun di negara berkembang. Review atas epidemi obesitas yang dilakukan Low, Chin dan Deurenberg-Yap $(2009)^{1}$ memperlihatkan bahwa prevalensi kelebihan berat (overweight) di negara maju berkisar dari 23,2 persen di Jepang hingga 66,3 persen di Amerika Serikat, sedangkan di negara berkembang berkisar dari 13,4 persen di Indonesia sampai 72,5 persen di Saudi Arabia. Adapun prevalensi kegemukan (obesity) di negara maju berkisar dari 2,4 persen di Korea Selatan hingga 32,2 persen di Amerika Serikat, sedangkan di negara berkembang berkisar dari 2,4 persen di Indonesia sampai 35,6 persen di Saudi Arabia. $^{1}$

World Health Organization (WHO $)^{2}$ memperkirakan, di dunia ada sekitar 1,6 milyar orang dewasa berumur $\geq 15$ tahun kelebihan berat dan setidak-tidaknya sebanyak 400 juta orang dewasa gemuk (obese) pada tahun 2005, dan diperkirakan lebih dari 700 juta orang dewasa akan gemuk (obese) pada tahun 2015. ${ }^{1}$ Di Indonesia, Riset Kesehatan Dasar (Riskesdas) 2007 menunjukkan bahwa 8,8 persen orang dewasa berumur $\geq 15$ tahun kelebihan berat dan 10,3 persen gemuk. ${ }^{3}$

Kegemukan atau obesitas merupakan kondisi ketidaknormalan atau kelebihan akumulasi lemak dalam jaringan adiposa. Berdasarkan Indeks Massa Tubuh (IMT), obesitas dibagi menjadi tiga kategori, yakni: Obesitas I, Obesitas II dan Obesitas III. Adapun berdasarkan distribusi lemak, obesitas dibagi menjadi dua kategori, yakni: obesitas sentral dan obesitas umum. Untuk penduduk Barat, seseorang dikatakan obesitas apabila IMT-nya $\geq 30 \mathrm{~kg} / \mathrm{m}^{2}$ atau lingkar perut $\geq 102 \mathrm{~cm}$ pada laki-laki dan $\geq$ $88 \mathrm{~cm}$ pada perempuan, sedangkan untuk 
penduduk Asia, IMT-nya $>25 \mathrm{~kg} / \mathrm{m}^{2}$ atau lingkar perut $\geq 90 \mathrm{~cm}$ pada laki-laki dan $\geq 80$ $\mathrm{cm}$ pada perempuan. ${ }^{2}$

Menurut WHO (2000), ${ }^{2}$ obesitas sentral adalah kondisi kelebihan lemak perut atau lemak pusat. Obesitas sentral lebih berhubungan dengan risiko kesehatan dibandingkan dengan obesitas umum. ${ }^{4,5}$ Prevalensi obesitas sentral pada penduduk Barat dan Timur tinggi. Prevalensi obesitas sentral pada laki-laki AS meningkat dari 37 persen (periode 1999-2000) menjadi 42,2 persen (periode 2003-2004), sedangkan prevalensi obesitas sentral pada perempuan AS meningkat dari 55,3 persen persen menjadi 61,3 persen pada periode yang sama. ${ }^{6}$ Pada laki-laki dan perempuan Eropa, obesitas sentral yang didefinisikan menurut kriteria lingkar perut definisi lokal (menggunakan nilai cut-off 90-102 cm untuk laki-laki dan 80-92 cm untuk perempuan) secara berturut-turut adalah 21 dan 24 persen di Belgia, 8 dan 13 persen di Perancis, 23 dan 65 persen di Spanyol, dan 18 dan 39 persen di Turki. ${ }^{5}$ Prevalensi obesitas sentral di Yunani 36 persen pada laki-laki dan 43 persen pada perempuan, ${ }^{7}$ China 16,1 persen pada laki-laki dan 37,6 persen pada perempuan, ${ }^{8}$ Omani 49,3 persen. ${ }^{9} \mathrm{Di}$ Indonesia, prevalensi obesitas sentral di Kota Padang sebesar 12,1 persen pada laki-laki dan 46,3 persen pada perempuan, ${ }^{10}$ di Denpasar sebesar 15,1 persen. $^{11}$ Riskesdas 2007 menemukan prevalensi obesitas sentral sebesar 18,8 persen. $^{3}$

Obesitas sentral dapat terjadi karena adanya perubahan gaya hidup seperti tingginya konsumsi minuman beralkohol, ${ }^{12,13}$ kebiasaan merokok, ${ }^{14,15}$ tingginya konsumsi makanan berlemak, ${ }^{16}$ rendahnya konsumsi sayuran dan buah, ${ }^{17,18}$ dan kurangnya aktivitas fisik. ${ }^{19,20}$ Selain itu, peningkatan umur, ${ }^{21}$ perbedaan jenis kelamin, ${ }^{22}$ dan status sosio-ekonomi ${ }^{8}$ diduga juga berhubungan dengan kejadian obesitas sentral.

Peningkatan prevalensi obesitas sentral berdampak pada munculnya berbagai penyakit degeneratif. Obesitas sentral berhubungan dengan peningkatan sindrom metabolik, ${ }^{4}$ aterosklerosis, ${ }^{23}$ penyakit kardiovaskuler, ${ }^{24,25}$ diabetes tipe-2, ${ }^{26,27}$ batu empedu, $^{28}$ gangguan fungsi pulmonal, ${ }^{29}$ hipertensi dan dislipidemia. ${ }^{30}$

Riskesdas 2007 merupakan pengejawantahan salah satu dari empat grand strategy Departemen Kesehatan, yakni berfungsinya sistem informasi kesehatan yang evidence-based melalui pengumpulan data dasar dan indikator kesehatan. ${ }^{3}$ Laporan Riskesdas 2007 baru memberikan informasi tentang obesitas sentral sebatas prevalensi dan belum menyajikan informasi tentang faktor-faktor risikonya. Riskesdas 2007 melaporkan bahwa ada dua provinsi berprevalensi obesitas sentral tertinggi, yaitu di Sulawesi Utara dan DKI Jakarta berturut-turut 31,5 dan 27,9 persen. $^{28}$ Terdapatnya jumlah sampel yang besar dan informasi yang luas pada Riskesdas 2007 serta tingginya prevalensi obesitas sentral di DKI Jakarta membuat penulis tertarik untuk menganalisis lebih lanjut faktor-faktor risiko obesitas sentral di DKI Jakarta.

Secara umum, penelitian ini bertujuan untuk menganalisis faktor-faktor risiko obesitas sentral pada orang dewasa di DKI Jakarta. Adapun tujuan khusus penelitian ini ialah untuk: (1) Menganalisis hubungan antara karakteristik demografi dan sosioekonomi dengan kejadian obesitas sentral; (2) Menganalisis hubungan antara gaya hidup dengan kejadian obesitas sentral; dan (3) Menganalisis faktor-faktor yang paling berpengaruh terhadap kejadian obesitas sentral.

\section{BAHAN DAN CARA}

\section{Desain, Tempat, dan Waktu}

Desain penelitian adalah crosssectional berskala nasional bersifat deskriptif. Data yang digunakan adalah data sekunder Riskesdas 2007 yang dilakukan oleh Badan Penelitian dan Pengembangan Kesehatan (Balitbangkes), Departemen Kesehatan RI. Provinsi DKI Jakarta diambil sebagai sampel penelitian karena memiliki prevalensi obesitas sentral yang tinggi dan di atas prevalensi nasional. Pengolahan dan 
analisis lanjut data dilakukan pada bulan Maret - Juni 2009 di Kampus IPB Dramaga Bogor, Jawa Barat.

\section{Jumlah dan Cara Pengambilan Sampel \\ Riskesdas 2007 menerapkan} rancangan sampel PPS (Probability proportional to size). Pemilihan sampel terdiri atas tiga tahap, yaitu: Pertama, diambil sejumlah blok sensus dari setiap kabupaten/ kota yang masuk dalam kerangka sampel yang proporsional terhadap jumlah rumah tangga di kabupaten/kota tersebut. Kedua, dari setiap blok sensus yang terpilih, diambil 16 rumah tangga secara acak sederhana (simple random sampling). Ketiga, seluruh anggota rumah tangga dari setiap rumah tangga yang terpilih diambil sebagai sampel individu. ${ }^{3}$ Metode yang digunakan hampir seluruhnya sama dengan Susenas (Survei Ekonomi Nasional) 2007 sehingga mudah dikorelasikan dengan data Susenas 2007. Sampel penelitian ini adalah orang dewasa berumur 15 tahun atau lebih yang tinggal di DKI Jakarta, tidak hamil, dan memiliki data lengkap. Total sampel dalam penelitian ini sebanyak 11805 sampel.

\section{Jenis dan Cara Pengumpulan Data}

Data dalam penelitian ini seluruhnya merupakan data Riskesdas 2007 yang diperoleh dalam bentuk electronic file. Data terdiri atas variabel umur, jenis kelamin, status perkawinan, besar keluarga, pendidikan, pekerjaan, pengeluaran per kapita, kebiasaan merokok, aktivitas fisik berat, konsumsi minuman beralkohol, konsumsi sayuran dan buah, konsumsi makanan manis, dan konsumsi makanan berlemak, kondisi mental emosional dan lingkar perut.

Pengambilan sampel dilakukan oleh tim Riskesdas 2007. Data karakteristik demografi dan sosio-ekonomi dan gaya hidup diperoleh tim Riskesdas 2007 dengan mewawancarai sampel menggunakan kuesioner terstruktur yang dilengkapi buku pedoman pengisian kuesioner. Data lingkar perut diperoleh dengan metode pengukuran menggunakan alat ukur yang terbuat dari fiberglass dengan presisi $0,1 \mathrm{~cm}$. Lingkar perut diukur pada titik tengah antara titik batas tepi tulang rusuk paling bawah dan titik ujung lengkung tulang pangkal paha/panggul pada ekspirasi normal.

\section{Pengolahan dan Analisis Data}

Data dianalisis menggunakan Microsoft Excell 2007 dan SPSS 15.0 for Windows. Tahap pengolahan data meliputi pemilihan variabel yang akan diteliti, cleaning dan recode variabel menjadi data kategori. Analisis data terdiri atas analisis univariat, bivariat, dan multivariat. Analisis univariat dilakukan untuk memperoleh gambaran distribusi frekuensi dan proporsi dari berbagai variabel yang diteliti. Analisis bivariat dilakukan untuk memperoleh ada tidaknya hubungan antara variabel bebas dan terikat dengan menggunakan korelasi Spearman dan Kontingensi. Korelasi Spearman digunakan untuk menguji hubungan variabel data ordinal, sedangkan Kontingensi untuk menguji hubungan variabel data nominal.

Variabel bebas yang diuji adalah variabel umur, jenis kelamin, status perkawinan, pendidikan, pekerjaan, pengeluaran per kapita, besar keluarga, tipe wilayah, kebiasaan merokok, aktivitas fisik berat, konsumsi minuman beralkohol, konsumsi sayuran dan buah, konsumsi makanan manis dan berlemak, dan kondisi mental emosional. Sementara variabel terikat adalah obesitas sentral.

Analisis multivariat dilakukan dengan menggunakan analisis regresi logistik yang bertujuan untuk mengetahui besar pengaruh variabel bebas terhadap variabel terikat. Variabel-variabel dengan nilai signifikan $p<0,25$ dipilih, kemudian dimasukkan dalam kandidat model multivariat. Analisis ini menggunakan model binary logistic regression dengan metode backward wald.

\section{HASIL DAN BAHASAN}

\section{Karakteristik Demografi dan Sosio- Ekonomi Umur}

Prevalensi obesitas sentral berdasarkan karakteristik demografi dan sosio-ekonomi 
ditunjukkan pada Tabel 1. Prevalensi obesitas sentral lebih tinggi pada sampel berumur 55 tahun atau lebih. Terdapat hubungan nyata positif antara umur dan kejadian obesitas sentral $(p<0,05)$. Hasil analisis sesuai dengan beberapa penelitian sebelumnya yang menemukan adanya hubungan antara umur dan kejadian obesitas sentral. ${ }^{31,21} \mathrm{Hal}$ ini diduga karena semakin bertambahnya umur seseorang, penumpukan lemak terutama daerah perut juga meningkat. ${ }^{21}$ Hasil analisis regresi logistik menunjukkan bahwa umur 35-54 tahun dan umur $\geq 55$ tahun berpeluang mengalami obesitas sentral berturut-turut 2.318 dan 2.723 kali lebih besar dibanding umur 15-34 tahun.

\section{Jenis kelamin}

Prevalensi obesitas sentral lebih tinggi pada perempuan daripada laki-laki. Dari hasil penelitian ditemukan hubungan nyata antara jenis kelamin dan kejadian obesitas sentral $(p<0,05)$. Hasil penelitian ini sejalan dengan beberapa penelitian sebelumnya yang menemukan hubungan nyata antara kejadian obesitas sentral dan jenis kelamin. ${ }^{31,32} \mathrm{Hal}$ ini diduga karena cadangan lemak tubuh lebih banyak terdapat pada perempuan. Erem et al. $(2004)^{32}$ menyatakan bahwa terdapatnya hubungan antara jenis kelamin dan kejadian obesitas sentral diduga karena perbedaan genetik, faktor diet, kurangnya aktivitas fisik berat antara laki-laki dan perempuan. Selain

\section{Besar keluarga}

Prevalensi obesitas sentral lebih tinggi pada sampel yang memiliki besar keluarga 1-2 orang. Hasil analisis menunjukkan bahwa terdapat hubungan nyata negatif antara besar keluarga dan kejadian obesitas sentral $(p<0,05)$. Hasil penelitian tidak sesuai dengan beberapa penelitian sebelumnya yang menemukan bahwa besar keluarga tidak berhubungan dengan obesitas., ${ }^{9,33}$ Terdapatnya hubungan nyata negatif antara besar keluarga dan kejadian obesitas sentral diduga karena besarnya keluarga mempengaruhi distribusi pangan yang akan diterima masing-masing individu. ${ }^{34}$ Hasil analisis regresi logistik menunjukkan bahwa itu, pada perempuan menopause terjadi penurunan massa otot dan perubahan status hormon (Lee et al. 2005). ${ }^{23}$ Hasil analisis regresi logistik menunjukkan bahwa perempuan berpeluang mengalami obesitas sentral 4.148 kali lebih besar daripada lakilaki.

\section{Status perkawinan}

Prevalensi obesitas sentral lebih tinggi pada sampel yang berstatus cerai. Hasil analisis menunjukkan hubungan nyata antara status perkawinan dan kejadian obesitas sentral $(p<0,05)$. Hasil penelitian sejalan dengan Erem et al. (2004) $)^{32}$ yang menemukan tingginya prevalensi obesitas pada sampel yang berstatus cerai. Tingginya prevalensi obesitas sentral pada sampel yang berstatus cerai diduga karena depresi yang dialami seseorang ketika bercerai. Kondisi stres atau depresi ini dapat menyebabkan gaya hidup yang tidak baik seperti konsumsi minuman beralkohol dan konsumsi makanan tinggi lemak. Kantachuvessiri et al. (2005) $)^{33}$ menyatakan bahwa seseorang yang mengalami depresi cenderung mengonsumsi makanan dalam jumlah yang berlebihan. Hasil analisis regresi logistik menunjukkan bahwa sampel yang berstatus kawin dan cerai berpeluang mengalami obesitas sentral berturut-turut 3.216 dan 2.434 kali lebih besar daripada sampel yang belum kawin.

tidak terdapat perbedaan peluang seseorang mengalami obesitas sentral menurut besar keluarga. Hal ini berarti bahwa berapapun besarnya anggota keluarga, peluang seseorang mengalami obesitas sentral sama.

\section{Pendidikan}

Prevalensi obesitas sentral sedikit lebih tinggi pada sampel yang tamat SD/SMP. Hasil analisis menunjukkan hubungan negatif antara pendidikan dan kejadian obesitas sentral. Hasil analisis sejalan dengan beberapa penelitian sebelumnya yang menyatakan bahwa pendidikan yang rendah berhubungan dengan peningkatan kejadian obesitas sentral. ${ }^{7,31}$ Pendidikan mempenga- 
ruhi pola pikir dan tingkat kepercayaan seseorang. ${ }^{35}$ Hasil analisis regresi logistik menunjukkan bahwa tidak terdapat perbedaan peluang seseorang mengalami obesitas sentral menurut pendidikan.
Hal ini berarti sampel yang tamat pendidikan tinggi ataupun rendah memiliki peluang yang sama mengalami obesitas sentral.

Tabel 1

Prevalensi Obesitas Sentral Berdasarkan Karakteristik Demografi dan Sosio-Ekonomi

\begin{tabular}{|c|c|c|c|}
\hline \multicolumn{2}{|c|}{ Variabel } & \multirow{2}{*}{$\begin{array}{l}\text { Obesitas } \\
\text { Sentral } \\
(\%)\end{array}$} & \multirow{2}{*}{$\begin{array}{c}\text { Koefisien } \\
\text { Korelasi } \\
(r)\end{array}$} \\
\hline Umur & $\begin{array}{l}15-34 \\
35-54 \\
\geq 55\end{array}$ & & \\
\hline Jenis kelamin & $\begin{array}{l}\text { Laki-laki } \\
\text { Perempuan }\end{array}$ & $\begin{array}{r}636(11.5) \\
2321(36.9)\end{array}$ & $0.281^{*}$ \\
\hline Status perkawinan & $\begin{array}{l}\text { Belum kawin } \\
\text { Kawin } \\
\text { Cerai hidup/mati }\end{array}$ & $\begin{array}{r}254(7.9) \\
2367(30.5) \\
336(41.3)\end{array}$ & $0.244^{*}$ \\
\hline Besar keluarga & $\begin{array}{l}1-2 \\
3-4 \\
5-6 \\
>6 \\
\end{array}$ & $\begin{array}{r}368(28.4) \\
1303(26.0) \\
902(24.5) \\
384(21.2) \\
\end{array}$ & $-0.043^{*}$ \\
\hline Pendidikan & $\begin{array}{l}\text { Tdk sekolah/tdk tamat SD } \\
\text { SD/SMP } \\
\text { SMA/PT }\end{array}$ & $\begin{array}{r}477(4.0) \\
1287(10.9) \\
1193(10.1)\end{array}$ & $-0.087^{*}$ \\
\hline Pekerjaan & $\begin{array}{l}\text { Tidak bekerja/sekolah } \\
\text { Ibu rumah tangga } \\
\text { TNI/POLRI/PNS } \\
\text { Pegawai BUMN/swasta }\end{array}$ & $\begin{array}{r}298(13.2) \\
1468(45.1) \\
91(24.4) \\
336(16.7)\end{array}$ & $0.297^{*}$ \\
\hline & $\begin{array}{l}\text { Wiraswasta/pedagang/jasa } \\
\text { Petani/nelayan/buruh } \\
\text { Lainnya }\end{array}$ & $\begin{array}{r}533(22.5) \\
135(12.7) \\
96(20.8) \\
\end{array}$ & \\
\hline Pengeluaran per kapita & $\begin{array}{l}\text { Kuintil } 1 \\
\text { Kuntil } 2 \\
\text { Kuintil } 3 \\
\text { Kuintil } 4 \\
\text { Kuintil } 5\end{array}$ & $\begin{array}{l}550(23.4) \\
562(23.7) \\
606(25.6) \\
601(25.6) \\
638(26.9)\end{array}$ & $0.029^{*}$ \\
\hline
\end{tabular}

*signifikan pada $p<0,05$

\section{Pekerjaan}

Prevalensi obesitas sentral lebih tinggi pada sampel yang bekerja sebagai ibu rumah tangga. Hasil penelitian menunjukkan hubungan nyata antara pekerjaan dan kejadian obesitas sentral $(p<0,05)$. Hasil penelitian sejalan dengan Erem et al.
$(2004)^{32}$ yang menemukan tingginya prevalensi obesitas pada ibu rumah tangga dan pedagang. Terdapatnya hubungan nyata antara pekerjaan dan kejadian obesitas sentral diduga karena berkaitan dengan aktivitas fisik berat yang melibatkan pengeluaran energi. Kantachuvessiri et al. 
$(2005)^{33}$ menyatakan bahwa penggunaan energi bervariasi pada tingkat aktivitas yang berbeda. Beberapa pekerjaan melibatkan tingginya penggunaan energi, sementara pekerjaan yang lain melibatkan sedikit pengeluaran energi. Hasil analisis regresi logistik menunjukkan bahwa ibu rumah tangga, pegawai BUMN/swasta, dan wiraswasta/ pedagang jasa berpeluang mengalami obesitas sentral berturut-turut adalah $1.419 ; 1.254 ; 1.290$ kali lebih besar daripada sampel yang tidak bekerja/sekolah.

\section{Pengeluaran per kapita}

Prevalensi obesitas sentral lebih tinggi pada sampel yang memiliki pengeluaran per kapita kuintil ke-5. Hasil analisis menunjukkan bahwa terdapat hubungan nyata positif antara pengeluaran per kapita dan kejadian obesitas sentral. Pengeluaran perkapita paralel dengan pendapatan

\section{Gaya Hidup \\ Kebiasaan merokok}

Prevalensi obesitas sentral berdasarkan gaya hidup disajikan pada Tabel 2 . Prevalensi obesitas sentral lebih tinggi pada sampel yang tidak pernah merokok. Hasil analisis menunjukkan bahwa terdapat hubungan nyata negatif antara merokok dan kejadian obesitas sentral. Hasil penelitian tidak konsisten dengan beberapa penelitian sebelumnya yang menemukan hubungan nyata positif antara merokok dan kejadian obesitas sentral. ${ }^{14,15,36}$ Terdapatnya hubungan antara merokok dan kejadian obesitas sentral diduga karena pengaruh merokok terdapat distribusi lemak, terutama pada daerah perut. Canoy et al. (2005) $)^{14}$ menyatakan bahwa meskipun merokok berhubungan dengan rendahnya IMT, tetapi merokok berhubungan dengan peningkatan kejadian obesitas sentral yang mencerminkan konsekuensi metabolik merokok. Kebiasaan merokok berpengaruh pada pola distribusi lemak. Hasil analisis regresi logistik menunjukkan bahwa tidak terdapat perbedaan peluang seseorang mengalami obesitas sentral menurut kebiasaan merokok. Hal ini berarti bahwa perkapita. Semakin tinggi pendapatan per kapita, semakin tinggi pula pengeluaran per kapita.

Beberapa penelitian sebelumnya menemukan bahwa pendapatan rumah tangga berhubungan positif dengan kejadian obesitas sentral. ${ }^{32,35}$ Hubungan antara pendapatan dan kejadian obesitas sentral terletak pada ketersediaan dalam membeli dan kemampuan dalam memanfaatkan akses seperti transportasi, kecanggihan komunikasi, ketersediaan pangan, pendidikan modern. Kemudahan dalam pemanfaatan akses mendorong seseorang cenderung kurang melakukan aktivitas fisik. ${ }^{2}$ Hasil analisis regresi logistik menunjukkan sampel yang memiliki pengeluaran per kapita kuintil ke- 5 berpeluang mengalami obesitas sentral 1.202 lebih besar daripada sampel yang memiliki pengeluaran per kapita kuintil ke-1.

seseorang yang merokok atau tidak merokok memiliki peluang yang sama untuk mengalami obesitas sentral.

\section{Konsumsi minuman beralkohol}

Prevalensi obesitas sentral lebih tinggi pada sampel yang tidak mengonsumsi minuman beralkohol. Hasil analisis menunjukkan bahwa konsumsi minuman beralkohol berhubungan nyata negatif dengan kejadian obesitas sentral $(p<0,05)$. Hasil penelitian ini tidak sejalan dengan beberapa penelitian sebelumnya yang menemukan hubungan nyata positif antara konsumsi minuman beralkohol dan kejadian obesitas sentral. ${ }^{12,13}$ Terdapatnya hubungan antara konsumsi minuman beralkohol dan kejadian obesitas sentral diduga karena kontribusinya terhadap total energi dan pengaruhnya terhadap metabolisme tubuh. Pada penelitian ini tidak diukur berapa banyak minuman beralkohol yang dikonsumsi. Selain itu, kelemahan desain cross-sectional study yang mengambil exposure dan outcome dalam waktu yang bersamaan sehingga tidak dapat menjelaskan hubungan sebab akibat antara konsumsi minuman beralkohol dan kejadian 
obesitas sentral. Hasil analisis regresi logistik menunjukkan bahwa tidak terdapat perbedaan peluang seseorang mengalami obesitas sentral menurut konsumsi minuman beralkohol. Hal ini berarti bahwa sampel yang mengonsumsi minuman beralkohol maupun tidak memiliki peluang yang sama mengalami obesitas sentral.

\section{Aktivitas fisik berat}

Prevalensi obesitas sentral lebih tinggi pada sampel yang tidak melakukan aktivitas fisik berat. Hasil analisis menunjukkan hubungan nyata negatif antara aktivitas fisik berat dan kejadian obesitas sentral. Hasil penelitian sejalan dengan beberapa penelitian sebelumnya yang menemukan hubungan nyata negatif antara aktivitas fisik dan kejadian obesitas sentral. ${ }^{37,38}$ Aktivitas fisik dapat menurunkan kejadian obesitas sentral melalui penggunaan lemak dari daerah perut, sebagai hasil redistribusi jaringan adiposa. ${ }^{39}$ Hasil analisis regresi logistik menunjukkan bahwa tidak terdapat perbedaan peluang seseorang mengalami obesitas sentral menurut aktivitas fisik berat. Tidak terdapatnya perbedaan pengaruh aktivitas fisik terhadap obesitas sentral diduga karena penelitian ini hanya menganalisis aspek kualitatif aktivitas fisik berat dan tidak menganalisis durasi dan frekuensi sampel dalam melakukan aktivitas fisik berat sehingga tidak menggambarkan kondisi sampel yang sebenarnya.

\section{Konsumsi sayuran dan buah}

Prevalensi obesitas sentral lebih tinggi pada sampel yang cukup mengonsumsi sayuran dan buah. Hasil analisis menunjukkan bahwa terdapat hubungan nyata positif antara konsumsi sayuran dan buah dengan kejadian obesitas sentral. Hasil analisis bertentangan dengan beberapa penelitian sebelumnya. Konsumsi sayuran dan buah dalam jumlah yang cukup dapat menurunkan kejadian obesitas sentral. ${ }^{18,40}$ Drapeau et al. (2004) ${ }^{17}$ menyatakan bahwa peningkatan konsumsi sayuran dan buah dapat menurunkan konsumsi lemak seseorang. Hasil analisis regresi logistik menunjukkan bahwa tidak terdapat perbedaan peluang seseorang mengalami obesitas sentral menurut konsumsi sayuran dan buah.

Ketidakkonsistenan hasil penelitian dengan penelitian sebelumnya dapat dijelaskan dengan beberapa alasan. Pertama, penelitian ini hanya mengukur frekuensi dan banyak porsi sayuran dan buah yang dikonsumsi dan tidak mengukur kandungan serat dalam sayuran dan buah yang dikonsumsi. Padahal serat berpengaruh terhadap kejadian obesitas sentral. Koh-Banerjee et al. (2003) ${ }^{39}$ menemukan bahwa asupan serat 12 gram/hari dapat menurunkan $0.63 \mathrm{~cm}$ lingkar perut dalam waktu 9 tahun. Kedua, kelemahan desain cross-sectional study yang mengambil exposure dan outcome dalam waktu yang bersamaan sehingga tidak dapat menjelaskan hubungan sebab akibat antara konsumsi sayuran dan buah dengan kejadian obesitas sentral. Kemungkinan pada waktu pengambilan data, sampel yang sebelumnya kurang mengonsumsi sayuran dan buah, mulai menyadari akan pentingnya konsumsi sayuran dan buah sehingga sudah mengubah kebiasaannya dengan mengonsumsi cukup sayuran dan buah.

\section{Konsumsi makanan manis}

Prevalensi obesitas sentral lebih tinggi pada sampel yang sering mengonsumsi makanan manis. Hasil analisis menunjukkan hubungan nyata negatif antara konsumsi makanan manis dan kejadian obesitas sentral. Hasil penelitian tidak sejalan dengan Drapeau et al. (2004) ${ }^{17}$ yang menyatakan bahwa konsumsi makanan manis dapat mengakibatkan peningkatan lingkar perut. Review Drewnowski $(2007)^{41}$ mengenai kontribusi makanan manis dan berlemak terhadap obesitas memperlihatkan bahwa mekanisme fisiologi mengapa konsumsi makanan manis meningkatkan lemak tubuh melibatkan tingginya densitas energi dan efek rasa lezat makanan manis dan sifat lemahnya kenyang.

Hasil analisis regresi logistik menunjukkan bahwa sampel yang sering mengonsumsi makanan manis berpeluang 
mengalami obesitas sentral 0.866 kali lebih besar daripada sampel yang jarang mengonsumsi makanan manis. Hal in berarti makanan manis dapat menurunkan kejadian obesitas sentral. Ketidakkonsistenan penelitian dengan penelitian sebelumya dapat dijelaskan dengan beberapa alasan. Pertama, pada penelitian ini tidak diukur besarnya kontribusi energi dari makanan manis yang dikonsumsi sehingga tidak dapat menggambarkan kondisi yang sebenarnya.

Tabel 2

Prevalensi Obesitas Sentral terhadap Gaya Hidup

\begin{tabular}{|c|c|c|c|}
\hline \multicolumn{2}{|c|}{ Variabel } & $\begin{array}{c}\text { Obesitas } \\
\text { Sentral (\%) }\end{array}$ & $\begin{array}{l}\text { Koefisien Korelasi } \\
\text { (r) }\end{array}$ \\
\hline Merokok & $\begin{array}{l}\text { Tidak pernah } \\
\text { Pernah merokok } \\
\text { Kadang kadang } \\
\text { Setiap Hari }\end{array}$ & $\begin{array}{r}2333(31.0) \\
145(22.8) \\
133(15.3) \\
346(12.4)\end{array}$ & $-0.188^{\star}$ \\
\hline Minuman beralkohol & $\begin{array}{l}\text { Tidak } \\
\text { Ya }\end{array}$ & $\begin{array}{r}2887(25.5) \\
70(13.9)\end{array}$ & $-0.044^{*}$ \\
\hline Aktivitas fisik berat & $\begin{array}{l}\text { Tidak } \\
\text { Ya }\end{array}$ & $\begin{array}{r}2618(26.4) \\
339(18.0) \\
\end{array}$ & $-0.070^{*}$ \\
\hline Sayuran dan buah & $\begin{array}{l}\text { Kurang } \\
\text { Cukup }\end{array}$ & $\begin{array}{r}2865(24.9) \\
92(30.7)\end{array}$ & $0.021^{*}$ \\
\hline Makanan manis & $\begin{array}{l}\text { Jarang } \\
\text { Sering }\end{array}$ & $\begin{array}{r}2048(24.0) \\
909(27.8) \\
\end{array}$ & $-0.046^{*}$ \\
\hline Makanan berlemak & $\begin{array}{l}\text { Jarang } \\
\text { Sering }\end{array}$ & $\begin{array}{r}656(26.0) \\
2301(24.8)\end{array}$ & $-0.024^{*}$ \\
\hline Kondisi mental emosional & $\begin{array}{l}\text { Tidak } \\
\text { Terganggu }\end{array}$ & $\begin{array}{r}2420(24.0) \\
537(31.1)\end{array}$ & $0.057^{\star}$ \\
\hline
\end{tabular}

\section{Konsumsi makanan berlemak}

Prevalensi obesitas sentral lebih tinggi pada sampel yang jarang mengonsumsi makanan berlemak. Hasil analisis menunjukkan bahwa terdapat hubungan negatif antara konsumsi makanan berlemak dan kejadian obesitas sentral $(p<0,05)$. Hasil penelitian tidak sejalan dengan beberapa penelitian sebelumnya yang menemukan hubungan antara konsumsi makanan berlemak dan peningkatan kejadian obesitas sentral. ${ }^{17,42}$
Kedua, banyaknya pemanis buatan di pasaran yang menggantikan pemanis alami tidak memberikan kontribusi energi yang tinggi. Ketiga, kelemahan desain crosssectional study yang mengambil exposure dan outcome dalam waktu yang bersamaan menyebabkan tidak dapat dijelaskannya hubungan antara konsumsi makanan manis dan kejadian obesitas sentral. 
Ketidakkonsistenan penelitian dengan beberapa penelitian sebelumnya diduga karena pada penelitian ini hanya ditanyakan frekuensi konsumsi makanan berlemak dan tidak mengukur besarnya kontribusi energi dari makanan berlemak yang dikonsumsi sampel sehingga hasil yang diperoleh tidak menggambarkan kondisi konsumsi makanan berlemak sampel sebenarnya. Hasil analisis regresi logistik menunjukkan bahwa sampel yang sering mengonsumsi makanan berlemak berpeluang mengalami obesitas sentral 1.216 kali lebih besar daripada sampel yang jarang mengonsumsi makanan berlemak.

\section{Kondisi mental emosional}

Prevalensi obesitas sentral lebih tinggi pada sampel yang kondisi mental emosionalnya terganggu. Hasil analisis menunjukkan bahwa terdapat hubungan nyata positif antara gangguan mental emosional dan kejadian obesitas sentral.

Tabel 3

Faktor Risiko Obesitas Sentral di DKI Jakarta

\begin{tabular}{|c|c|c|c|c|c|}
\hline \multirow{2}{*}{ Variabel } & \multirow{2}{*}{ B } & \multirow{2}{*}{ Sig. } & \multirow{2}{*}{ OR } & \multicolumn{2}{|c|}{$95,0 \% \mathrm{Cl}$ for OR } \\
\hline & & & & Lower & Upper \\
\hline \multicolumn{6}{|l|}{ Umur (0=15-34 tahun) } \\
\hline - 35-54 tahun & 0.841 & 0.000 & 2.318 & 2.069 & 2597 \\
\hline - $\quad \geq 55$ tahun & 1.002 & 0.000 & 2723 & 2.330 & 3.183 \\
\hline \multicolumn{6}{|l|}{ Jenis kelamin ( $0=$ laki-laki) } \\
\hline - Perempuan & 1.431 & 0.000 & 4.184 & 3.561 & 4.915 \\
\hline \multicolumn{6}{|l|}{ Status perkawinan (0=belum kawin) } \\
\hline - Kawin & 0.947 & 0.000 & 2.579 & 2.162 & 3.076 \\
\hline - Cerai & 0.794 & 0.000 & 2.213 & 1.756 & 2.789 \\
\hline \multicolumn{6}{|l|}{ Pekerjaan (0=tidak bekerja/sekolah) } \\
\hline - Ibu rumah tangga & 0.350 & 0.000 & 1.419 & 1.184 & 1.702 \\
\hline - Pegawai BUMN/swasta & 0.227 & 0.021 & 1.254 & 1.035 & 1.520 \\
\hline - Wiraswasta/pedagang/jasa & 0.254 & 0.006 & 1.290 & 1.076 & 1.546 \\
\hline \multicolumn{6}{|l|}{ Pengeluaran per kapita (0=kuintil ke- 1 ) } \\
\hline - Kuintil 5 & 0.184 & 0.015 & 1.202 & 1.037 & 1.392 \\
\hline \multicolumn{6}{|l|}{ Kebiasaan merokok (0=tidak merokok) } \\
\hline - Pernah merokok & 0.250 & 0.031 & 1.284 & 1.023 & 1.342 \\
\hline \multicolumn{6}{|l|}{ Makanan manis (0=jarang) } \\
\hline$\bullet \quad$ Sering & -0.144 & 0.005 & 0.866 & 0.782 & 0.958 \\
\hline \multicolumn{6}{|l|}{ Makanan berlemak (0=jarang) } \\
\hline$\bullet \quad$ Sering & 0.195 & 0.001 & 1.216 & 1.087 & 1.360 \\
\hline \multicolumn{6}{|l|}{ Kondisi mental emosional (0=tidak) } \\
\hline - $\quad$ Terganggu & 0.126 & 0.046 & 1.135 & 1.002 & 1.285 \\
\hline - Konstan & -3.516 & 0.000 & 0.030 & & \\
\hline
\end{tabular}

Lee et al $(2005)^{23}$ menyatakan bahwa stres atau depresi berhubungan pada peningkatan lingkar perut. Terdapatnya hubungan antara kondisi mental emosional terganggu dan kejadian obesitas sentral diduga karena seseorang yang mengalami gangguan 
mental emosional cenderung mengonsumsi makanan dalam jumlah berlebihan. ${ }^{33}$ Perubahan hormon pada seseorang yang mengalami depresi atau stres diduga juga dapat menyebabkan peningkatan penumpukan lemak tubuh, terutama di

\section{SIMPULAN DAN SARAN}

\section{Simpulan}

Prevalensi obesitas sentral lebih tinggi pada perempuan berumur 55 tahun atau lebih, berstatus ibu rumah tangga, bercerai, sekolah tamat SD/SMP, besar keluarga 1-2 orang, berpengeluaran perkapita kuintil ke-5, tinggal di perkotaan, tidak merokok, tidak mengonsumsi minuman beralkohol, tidak melakukan aktivitas fisik berat, cukup mengonsumsi sayuran dan buah, sering mengonsumsi makanan manis, jarang mengonsumsi makanan berlemak dan terganggu kondisi mental emosionalnya.

Hasil analisis korelasi Kontingensi menunjukkan bahwa jenis kelamin, status perkawinan, pekerjaan, dan tipe wilayah tinggal berhubungan nyata dengan kejadian obesitas sentral. Adapun hasil analisis korelasi Spearman menunjukkan bahwa umur, pengeluaran per kapita, konsumsi sayuran dan buah dan gangguan mental emosional berhubungan nyata positif dengan kejadian obesitas sentral. Sementara besar keluarga, merokok, konsumsi minuman beralkohol, aktivitas fisik berat, konsumsi makanan manis, dan konsumsi makanan berlemak berhubungan nyata negatif dengan kejadian obesitas sentral.

Faktor risiko obesitas sentral di DKI Jakarta adalah perempuan berumur $\geq 35$ tahun; berstatus kawin, cerai, ibu rumah tangga; pegawai BUMN/swasta; wiraswasta/ pedagang/jasa; pengeluaran per kapita kuintil ke-5, pernah merokok, mengonsumsi makanan berlemak, dan kondisi mental emosional terganggu. Sementara konsumsi makanan manis merupakan faktor risiko yang dapat menurunkan kejadian obesitas sentral. Faktor risiko yang paling dominan daerah perut. Hasil penelitian menunjukkan bahwa sampel yang kondisi mental emosionalnya terganggu berpeluang mengalami obesitas sentral 1.135 kali lebih besar daripada sampel yang tidak mengalami gangguan mental emosional.

terhadap kejadian obesitas sentral di DKI Jakarta adalah perempuan.

\section{Saran}

Mengingat tingginya prevalensi obesitas sentral di DKI Jakarta, diperlukan upaya pencegahan dan pengelolaan obesitas sentral. Bagi masyarakat, sebaiknya melakukan aktivitas fisik berat yang cukup, menghindari gangguan mental emosional, dan mengatur pola makan yang sehat seperti mengurangi konsumsi makanan berlemak. Bagi pemerintah, sebaiknya dilakukan promosi kesehatan mengenai faktor risiko obesitas sentral dan dampaknya terhadap kesehatan. Karena pada penelitian ini masih terdapat perdebatan berkenaan dengan hasil, sebaiknya dilakukan penelitian lanjutan untuk memperjelas hubungan antara gaya hidup dan kejadian obesitas sentral.

\section{RUJUKAN}

1. Low S, Chin MC, Deurenberg-Yap M. Review on epidemic of obesity. Ann Acad Med Singapore. 2009; 38: 57-65.

2. WHO. Obesity: Preventing and Managing the Global Epidemic. Report of a WHO consultation. Geneva, Switzerland: WHO, 2000.

3. Badan Penelitian dan Pengembangan Kesehatan Depkes RI. Riset Kesehatan Dasar 2007. Jakarta: Balitbangkes Depkes RI, 2008.

4. Shen $W$ et al. Waist circumference correlates with metabolic syndrome indicators better than percentage fat. Obesity. 2006;14:727-36.

5. Wittchen HU et al. International day for the evaluation of abdominal obesity: rationale and design of a primary care study on the prevalence of abdominal 
obesity and associated factors in 63 countries. Eur Heart J. 2006; 8(suppl B): B26-33.

6. Li C et al. Increasing trends in waist circumference and abdominal obesity among U.S. adults. Obesity. 2007;15:216-24.

7. Panagiotakos DB et al. Epidemiology of overweight and obesity in a Greek adult population: the ATTICA Study. Obes Res. 2004;12:1914-20.

8. Reynolds $\mathrm{K}$ et al. Prevalence and risk factors of overweight and obesity in China. Obesity. 2007;15:10-18.

9. Al-Riyami A and Afifi MM. 2003. Prevalence and correlates of obesity and central obesity among Omani adults. Saudi Med J. 2003;24(6):641-46.

10. Kamso S. Dislipidemia dan obesitas sentral pada lanjut usia di Kota Padang. J Kes Mas Nas. 2007;2(2):73-77.

11. Gotera W et al. 2006. Hubungan antara obesitas sentral dengan adiponektin pada pasien geriatri dengan penyakit jantung koroner. J Peny Dalam. 2006;7(2):102-07.

12. Dorn JM et al. 2003. Alcohol drinking patterns differentially affect central adiposity as measured by abdominal height in women and men. J. Nutr. 2003;133:2655-62.

13. Rise'rus $U$ and Ingelsson E. Alcohol intake, insulin resistance, and abdominal obesity in elderly men. Obesity. 2007;15:1766-73.

14. Canoy $D$ et al. Cigarette smoking and fat distribution in 21,828 British men and women: a population based study. Obes Res. 2005;13:1466-75.

15. Xu F, XM Yin, $Y$ Wang. The association between amount of cigarettes smoked and overweight, central obesity among Chinese adults in Nanjing, China. Asia Pac J Clin Nutr. 2007;16(2):240-47.

16. Garaulet $\mathrm{M}$ et al. Endocrine, metabolic and nutritional factors in obesity and their relative significance as studied by factor analysis. Int $\mathrm{J}$ Obes. 2001;25:243-51.

17. Drapeau $\mathrm{V}$ et al. Modifications in foodgroup consumption are related to longterm body-weight changes. Am J Clin Nutr. 2004;80:29-37.

18. Newby PK et al. Dietary patterns and changes in body mass index and waist circumference in adults. Am J Clin Nutr. 2003;77:1417-25.

19. Slentz CA et al. Effects of the amount of exercise on body weight, body composition, and measures of central obesity. Arch Intern Med. 2004;164:3139.

20. Besson $\mathrm{H}$ et al. A cross-sectional analysis of physical activity and obesity indicators in European participants of the EPIC-PANACEA study. Int $J$ Obes. 2009;1-10.

21. Martins IS and Marinho SP. The potential of central obesity antropometric indicators as diagnostic tools. Rev Saúde Pública. 2003;37(6).

22. Dekkers JC et al. Development of general and central obesity from childhood into early adulthood in African American and European American males and females with a family history of cardiovascular disease. Am J Clin Nutr. 2004;79:661-68.

23. Lee ES et al. Depressive mood and abdominal fat distribution in overweight premenopausal women. Obes Res. 2005;13:320-25.

24. Baik I et el. Adiposity and mortality in men. Am J Epidemiol. 2000;152:264-71.

25. Wildman RP, Gu D, Reynolds K, Duan $X, \mathrm{Wu} X, \mathrm{He} J$. Are waist circumference and body mass index independently associated with cardiovascular disease risk in Chinese adults? Am J Clin Nutr. 2005;82:1195-202.

26. Wang Y, Rimm EB, Stampfer MJ, Willett WC, Hu FB. Comparison of abdominal 
adiposity and overall obesity in predicting risk of type 2 diabetes among men. Am J Clin Nutr. 2005;81:555-63.

27. Krishnan S, Rosenberg L, Djousse L, Cupples A, Palmer JR. Overall and central obesity and risk of type 2 diabetes in U.S. black women. Obesity. 2007;15:1860-66.

28. Tsai C, Leitzmann MF, Willett WC, Giovannucci EL. Prospective study of abdominal adiposity and gallstone disease in US men. Am J Clin Nutr 2004;80:38-44.

29. Chen Y, Rennie D, Cormier YF, Dosman J. Waist circumference is associated with pulmonary function in normal-weight, overweight, and obese subjects. Am J Clin Nutr. 2007;85:35-9.

30. Barbagallo $\mathrm{CM}$ et al. Prevalence of overweight and obesity in a rural southern Italy population and relationships with total and cardiovascular mortality: the Ventimiglia di Sicilia project. Int $J$ Obes. 2001;25:185-90.

31. Janghorbani $M$ et al. First nationwide survey of prevalence of overweight, underweight, and abdominal obesity in Iranian adults. Obesity. 2007;15:27972808.

32. Erem $\mathrm{C}$ et al. Prevalence of obesity and associated risk factors in a Turkish population (Trabzon City, Turkey). Obes Res. 2004;12:1117-27.

33. Kantachuvessiri A et al. Factors associated with obesity among workers in a metropolitan waterworks authority. Southeast Asian J Trop Med Public Health. 2005;36:1057-65.

34. Adiningrum RD. Karakteristik kegemukan pada anak sekolah dan remaja di Medan dan Jakarta selatan. [Skripsi]. Bogor: Fakultas Pertanian IPB, 2008.

35. Yoon YS, SW HS Oh, Park. Socioeconomic status in relation to obesity and abdominal obesity in
Korean adults: a focus on sex differences. Obesity. 2006;14:909-19.

36. Chiolero, A. David, F. Fred, P. Jacques, C. Consequences of smoking for body weight, body fat distribution, and insulin resistence. $A m$ J Clin Nutr. 2008;87:801-09.

37. Irwin ML et al. Effect of exercise on total and intra-abdominal body fat in postmenopausal women: a randomized controlled trial. JAMA. 2003;289(3):32330.

38. McTiernan A et al. 2007. Exercise effect on weight and body fat in men and women. Obesity. 2007;15:1496-1512.

39. Koh-Banerjee $P$ et al. Prospective study of the association of changes in dietary intake, physical activity, alcohol consumption, and smoking with 9-y gain in waist circumference among 16587 US men. Am J Clin Nutr. 2003;78:71927.

40. He $\mathrm{K}$ et al. Changes in intake of fruits and vegetables in relation to risk of obesity and weight gain among middleaged women. Int J Obes. 2004;28:1569157

41. Drewnowski $A$. The real contribution of added sugars and fats to obesity. Epidemiol Rev. 2007;29:160-171.

42. Guallar-Castillon $P$ et al. Intake of fried foods is associated with obesity in the cohort of Spanish adults from the European prospective investigation into cancer and nutrition. Am J Clin Nutr. 2007;86:198-205. 